\title{
LINKING MONEY SUPPLY WITH THE GROSS DOMESTIC PRODUCT IN ROMANIA
}

\author{
Daniela Zapodeanu ${ }^{1}$ \\ Mihail Ioan Cociuba ${ }^{2}$
}

\begin{abstract}
Evolution of money supply and gross domestic product are in a close relationship, in this paper we analysis this relationship in order to construct a function which will explicit this connection for Romania. Evolution of gross domestic product is one with a seasonal component so from the data series we will be eliminating seasonality with the X-12 ARIMA method. Analyzing the data of money supply (M3) and of GDP over ten years through the Augmented Dickey-Fuller we obtained that both series are non-stationary. Applying the co-integration analysis method EngleGranger we conclude that the two series have a cointegration relationship between them. We will propose a model explanation of the link between the two sets of data type, a DVAR model.
\end{abstract}

Key words: money supply (M3), GDP, seasonality, stationarity, cointegration, DVAR.

JEL codes:G17, C51.

\section{Fundamentals notions.}

Starting from the well known quantity theory of money of Irving Fisher: $M * V=P * Q$, where $\mathrm{M}$ is money, $\mathrm{V}$ - velocity of money, $\mathrm{P}$ - price level and $\mathrm{Q}$ - the quantity of goods and services from an economy, we try to analyze the relationship between GDP (value of goods and services in a country) and money. Highlighting the long-term stable relationship between money growth and inflation, usually indicates that monetary mass is within the increase in economic activity (GDP) [Zăpodeanu, 2002: 31].

Analysis conducted in other countries showed that money demand function is a function which is not stable over time [Blundell-Wignall, 1984] -because of changes that may occur in the interest rate and inflation expectations, or either because of changes in function itself ( changing its on structure). Analyzing the demand for money in Austria [Hayo, 2000] through a VAR a model (vector autoregressive model) notes that the demand for money is stable, having an elastic monetary aggregate M1 uniform and independent on to GDP rate, while M1 and M2 monetary aggregates are influenced by income level and long-term interest rate (inverse relationship), for the euro zone [Brand et all, 2000] uses a structural cointegrated VAR model for the money demand (M3) and finds a relations between long-term interest rates and GDP. The analysis of demand for money in Venezuela [Cuevas, 2002] shows that the best function used is VECM (vector error correction model), which achieves a positive subunit elasticity of demand for currency in relation with GDP and a negative subunit elasticity to inflation. Analyzing the demand for money in transition economies [Ozturk, Acaravci, 2008] using an feasible least squares model (FGLS) found a long-run positively connection with real GDP and an inverse relationship with inflation and real effective exchange rate. Analyzing the Czech Republic [Bednarik, Radek, 2010] use the VAR method for analyzing the relationship between money supply and GDP, using co-integration test notes that the

1 University of Oradea, Faculty of Economics, danizapodeanu@yahoo.com

2 University of Oradea, Faculty of Economics, cociuba@gmail.com 
two series are not co-integrated, and for the Granger causality test they concluded that there isn't any causality between the two series. In conclusion to build money demand function it should be analyzed the data sets, using specific tests and then testing the obtained models. This paper will analyze the connection between the GDP and money series in order to build a capable function, which will correctly explicit monetary and economic realities.

We will define money as "non-bank agents all claims on the banking system", it is formed according to the $\mathrm{NBR}^{3}$ method from three monetary aggregates: the narrow money (M1) which comprises currency in circulation (notes and coins) and deposits immediately convertible into cash or which can be used for payments via bank transfer overnight deposits; intermediate money (M2) comprises narrow money in the (M1) and deposits with initial term of up to two years including deposits redeemable at notice up to 3 months including. The definition of M2 mirrors the interest in analyzing and monitoring a monetary aggregate which, apart from cash, includes deposits with high liquidity; broad money (M3) comprises intermediate money (M2), plus marketable instruments issued by monetary financial institution's sector; money market instruments, especially shares / units of money market funds and borrowings from repurchase agreements are included in the aggregate (greater liquidity makes these instruments be substitutes for deposits).

\section{Data used and methodology}

The data used are gross domestic product (GDP) and broad money (M3) and the monetary aggregates M1 and M2, the series of data were obtained from monthly reports NBR for M1, M2, M3 and the base of Eurostat for GDP They span the period between 1999 - 2010, the data used are quarterly, the number of observations is $45^{4}$. In the research has been used the open source software for econometric analysis Gretl (GNU regression, Econometrics and Time-series Library).

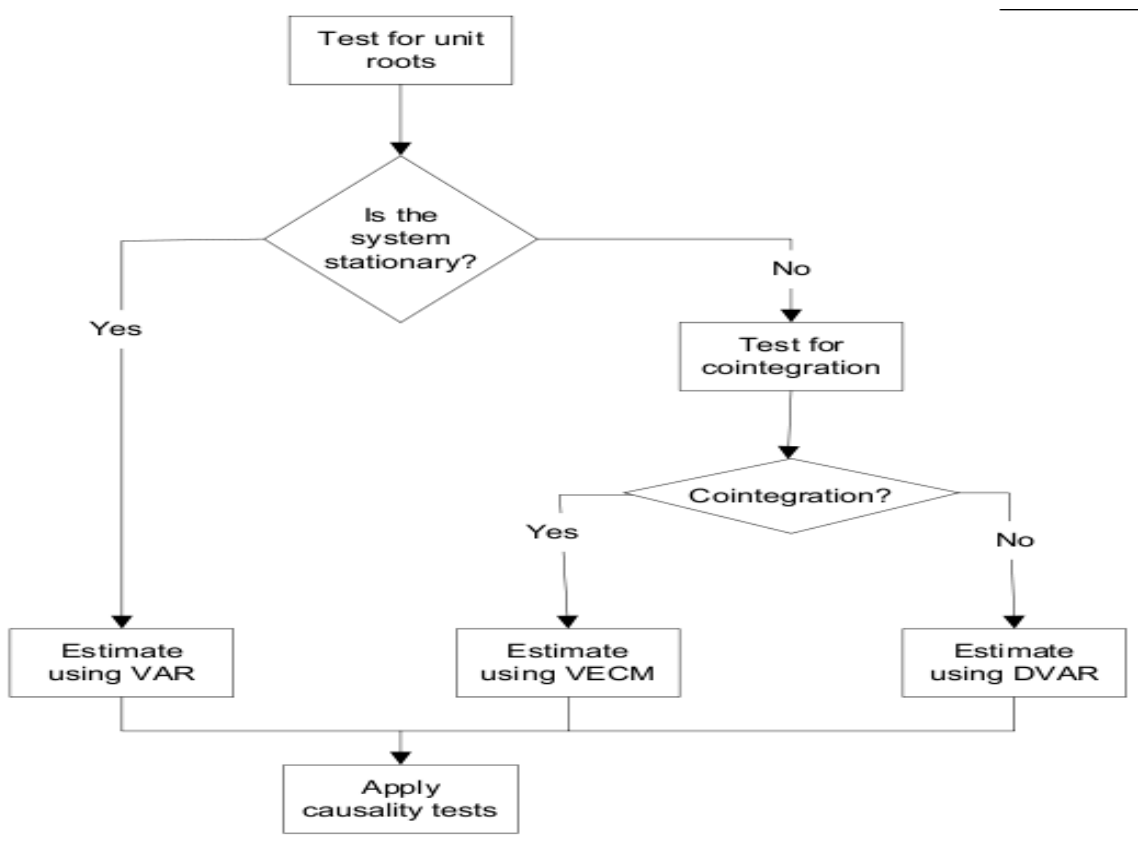

Fig. no 1.- Methodology of Granger causality test

(Sursa : Pop Silaghi, M.I. , Exports-Economic growth causality: Evidence from CEE Countries, pg.108, Romanian

3 The same methodology is applied to the ECB.

4 The data used are given in The Appendix. 
Journal of Economic Forecasting,pg. 108, no. 2/2009,http://www.ipe.ro/rjef.htm)

The research carried out has the following structure: a graphical analysis of data series, seasonality analysis for GDP (and elimination), stationary series analysis (ADF test), testing cointegration, proposed models, causality analysis.
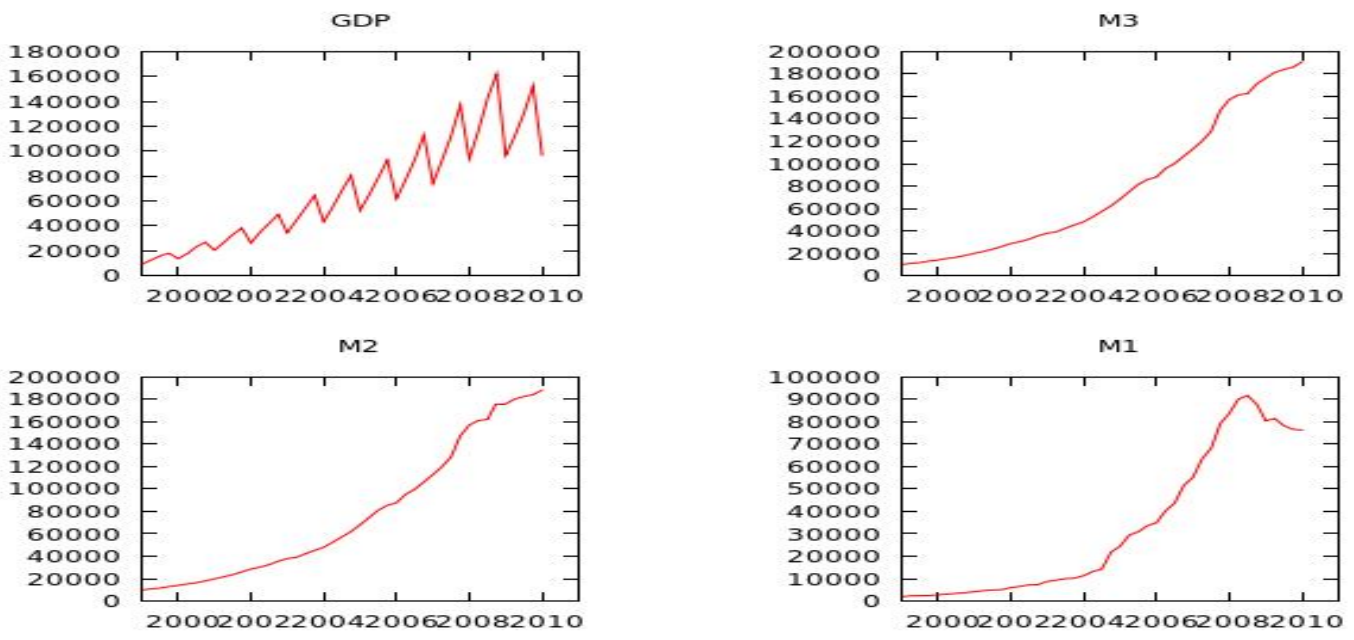

Fig. no 2 - Graphical analysis of time series GDP, M1, M2, M3

Representation of data series shows that GDP has a strong seasonality, which will be removed using the X-12 ARIMA methodology used by the U.S. Bureau of Statistics, on the broad money supply and monetary aggregates M1,M2 series is noted that this are no stationary series; in order to make them stationary they need to be differentiated. The money aggregates have a continuous growth rate, except for M1, the explanation for the narrow monetary aggregate decline lies in the fact that due to economic crisis the revenues decreased, and also the decline in circulation cash.
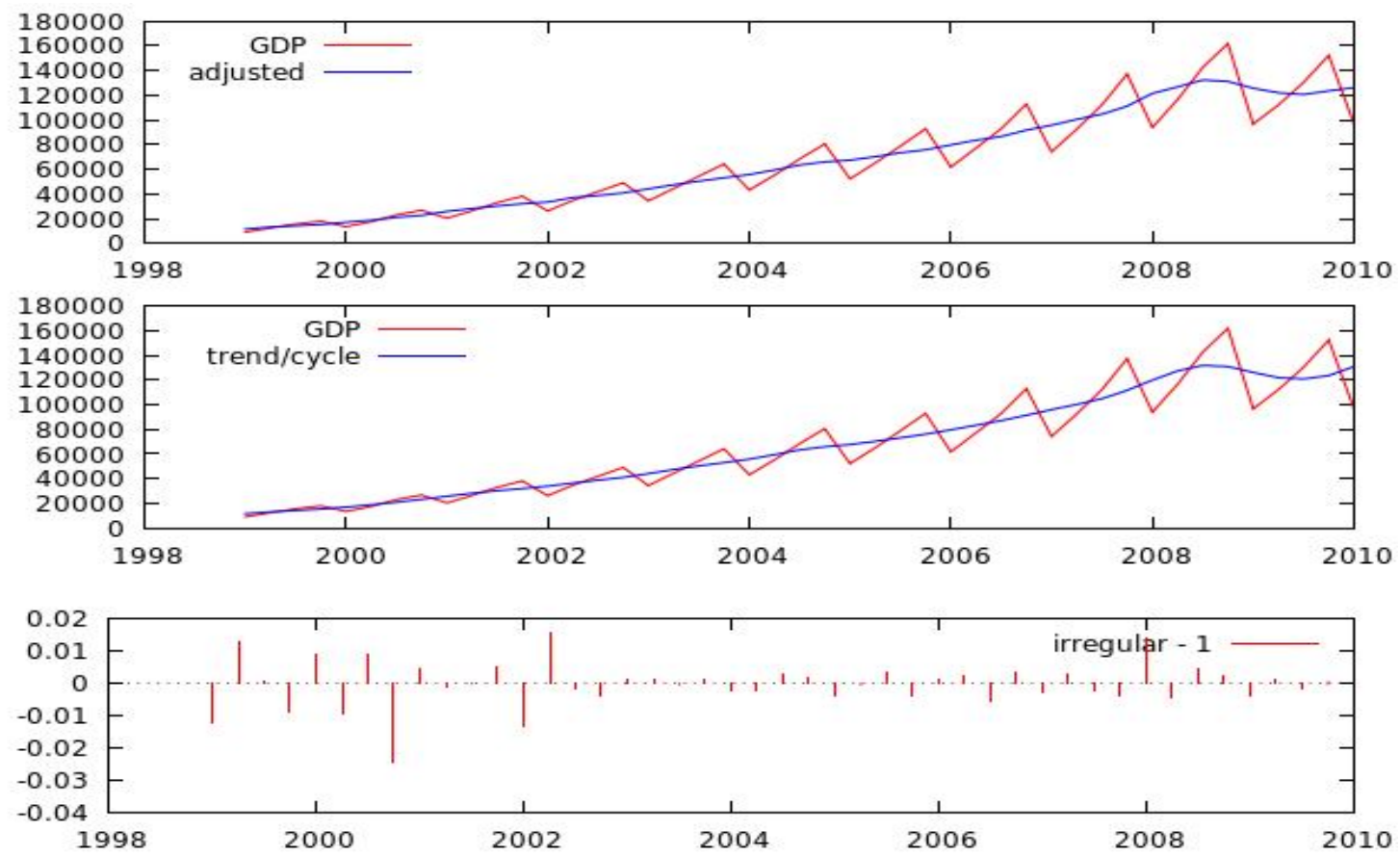

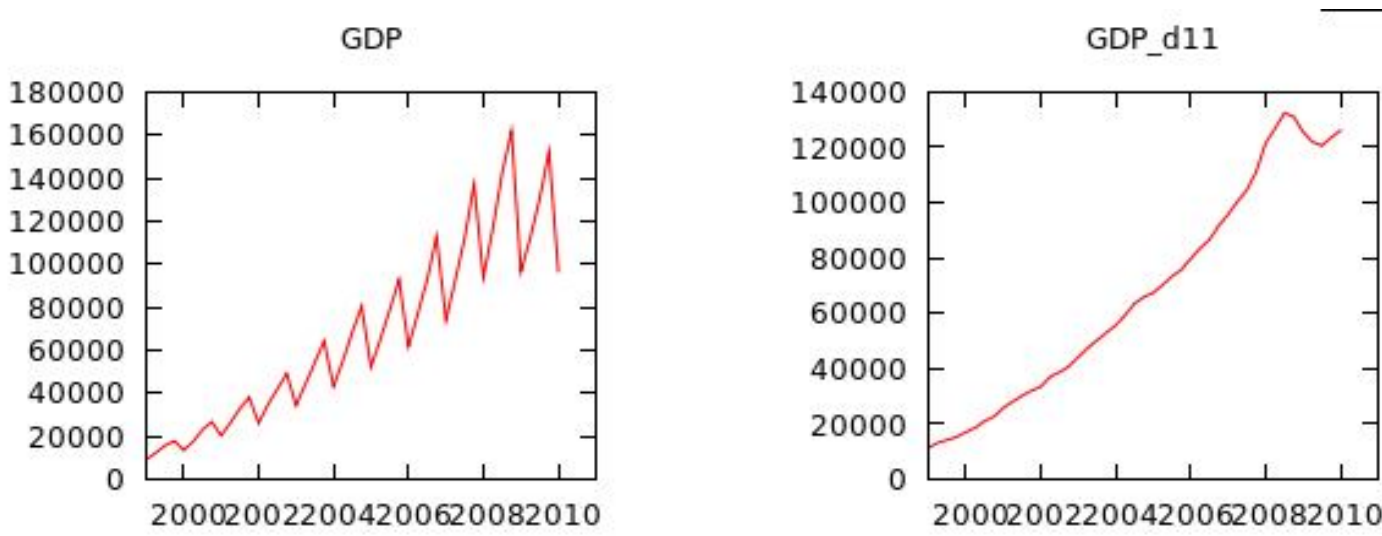

Fig. no 3 - GDP Seasonality

\section{Analyzing the series stationarity}

The stationarity concept was defined in the work of Box-Jenkins [1984], stationarity implies that the process is invariably if analyzed in time, these conditions must be met: the average of time series are constant and series variance is constant..[Codirlasu, 2008] If a stationary process is affected by a stochastic shock effect, in time it will disappear, because of non-persistent errors property. [Mester, 2007] For analyzing stationarity the most used test is the Augmented Dickey Fuller test, which is a test that estimated by the method of least squares the equation:

$$
\Delta \mathrm{y}_{\mathrm{t}}=\delta \mathrm{y}_{\mathrm{t}-1}+\Sigma \gamma_{\mathrm{j}} * \Delta \mathrm{y}_{\mathrm{t}-\mathrm{j}}+\alpha+\beta * \mathrm{t}^{+} \mathrm{v}_{\mathrm{t}}
$$

It will test the hypotheses: $\mathrm{H}_{0}: \delta=1$ and $\quad \mathrm{H}_{1}: \delta<1$

ADF Tests

\begin{tabular}{|l|l|l|l|}
\hline $\begin{array}{l}\text { Series } \\
\text { Name }\end{array}$ & F- Statistic & Probability & $\begin{array}{l}\text { Stationary } \\
\text { series }\end{array}$ \\
\hline GDP $^{5}$ & -0.4262 & 0.90 & No \\
\hline M3 & -1.786 & 0.71 & NO \\
\hline d_GDP & -1.829 & 0.06 & Yes, P>90\% \\
\hline d_M3 & -3.290 & 0.02 & Yes, P>95\% \\
\hline
\end{tabular}

According to tests conducted we conclude that M3 and GDP series are not stationary, but their first difference, or d_M3 d_GDP, are stationary and so further analysis will be made to see whether the series are cointegrated.

5 Gross domestic product is tested by eliminating seasonality

6 It tests the first difference of variables GDP and M3 


\section{Testing cointegration}

Cointegration is a statistical property of time series, if two or more series are not integrated individually, but a linear combination of them has a lower order of integration, then the series are said to be co-integrated. Co-integration is a methodology of testing hypotheses about the relationship between two variables having unit roots, the test is: testing stationarity series. First we use a series of linear regression between money supply and gross domestic product using the method of least squares, then testing stationarity for residuals, this is achieved by applying the ADF test on the residuals, if they are stationary then the series are co-integrated, or otherwise they are not co-integrated.

\section{Step 1: cointegrating regression}

OLS, using observations 1999:1-2010:1 $(\mathrm{T}=45)$

Dependent variable: GDP_d11

$\begin{array}{lllll} & \text { coefficient } & \text { std. error } & \text { t-ratio } & \text { p-value } \\ \text { const } & 16662.6 & 1824.68 & 9.132 & 1.26 \mathrm{e}-11 \text { *** } \\ \text { M3 } & 0.647050 & 0.0186637 & 34.67 & 4.61 \mathrm{e}-33 * * *\end{array}$

\section{Step 2: testing for a unit root in uhat (ADF test)}

including one lag of (1-L)uhat

sample size 43

unit-root null hypothesis: $\mathrm{a}=1$

model: $(1-\mathrm{L}) \mathrm{y}=\mathrm{b} 0+(\mathrm{a}-1) * \mathrm{y}(-1)+\ldots+\mathrm{e}$

1st-order autocorrelation coeff. for e: 0.029

estimated value of $(\mathrm{a}-1)$ : -0.0967796

test statistic: tau_c(2) $=-1.76596$

asymptotic p-value 0.647

The first step of the test is to achieve a type of linear regression $y=a * x+$ uhat, in this cae GDP variable is considered dependent and the explanatory variable is the money series. Residuals values are then analyzed using the ADF test, where it appears that they are not integrated of order zero I (0), with a probability of over $64 \%$. Same test also shows that there is a possibility of integration of order one I (1) of uhat (residuals) series. The model will be one of the types of vector model DVAR, autoregressive the difference. VAR model allows symmetrical treatment of all variables in the model, implicitly assumes that a certain variable is not exogenous and it is intended to be used when the one doesn't know for sure if a variable is exogenous.

In a VAR model with two variables the evolution of $x$ variable will be influenced by past values (lag-s) of $x$, and current and previous values of $y$. Also, we assume that $y$ is affected by lagged values of him, and current or previous values of $\mathrm{x}$. Therefore, the system bi-variate simple (primitive form of the system) is described as follows:

$$
\begin{aligned}
& x_{t}=a_{11}+a_{12} x_{t-1}+a_{13} y_{t}+a_{14} y_{t-1}+\varepsilon_{x t} \\
& y_{t}=a_{21}+a_{22} y_{t-1}+a_{23} x_{t}+a_{24} x_{t-1}+\varepsilon_{z t}
\end{aligned}
$$

-where it is assumed that both $\mathrm{x}$ and $\mathrm{y}$ are stationary variables and ext and ezt are white and uncorrelated noise (also true in general for a VAR model).

Model is obtained as: 
VAR system, lag order 6

OLS estimates, observations 2000:4-2010:1 $(T=38)$

Equation 1: d_M3

$\begin{array}{lcccc} & \text { coefficient } & \text { std. error } & \text { t-ratio } & \text { p-value } \\ \text { const } & 1681.84 & 1848.51 & 0.9098 & 0.3716 \\ \text { d_M3_1 } & 0.652607 & 0.209131 & 3.121 & 0.0045\end{array}$ ****

Equation 2: d_GDP_d11

$\begin{array}{lccccc} & \text { coefficient } & \text { std. error } & \text { t-ratio } & \text { p-value } \\ \text { const } & 3139.31 & 809.627 & 3.877 & 0.0007 & * * * \\ \text { d_M3_1 } & 0.465694 & 0.0915971 & 5.084 & 3.00 \mathrm{e}-05 & * * * \\ \text { d_M3_2 } & 0.109037 & 0.130108 & 0.8381 & 0.4099 & \\ \text { d_M3_3 } & 0.255453 & 0.106954 & 2.388 & 0.0248 & * * \\ \text { d_M3_4 } & -0.00486469 & 0.0943254 & -0.05157 & 0.9593 & \\ \text { d_M3_5 } & -0.343428 & 0.102250 & -3.359 & 0.0025 & * * * \\ \text { d_M3_6 } & 0.111044 & 0.137254 & 0.8090 & 0.4261 & \\ \text { d_GDP_d11_1 } & 0.176880 & 0.201664 & 0.8771 & 0.3888 & \\ \text { d_GDP_d11_2 } & -0.0195679 & 0.193711 & -0.1010 & 0.9203 & \\ \text { d_GDP_d11_3 } & 0.0168844 & 0.156033 & 0.1082 & 0.9147 & \\ \text { d_GDP_d11_4 } & -0.412313 & 0.152031 & -2.712 & 0.0119 & * * \\ \text { d_GDP_d11_5 } & -0.201157 & 0.243063 & -0.8276 & 0.4157 & \\ \text { d_GDP_d11_6 } & -0.540244 & 0.256033 & -2.110 & 0.0450 & * *\end{array}$

From the results we can conclude that the monetary aggregates (M3) are influenced only by it's lags, respectively lag 1 and 4; the evolution of GDP is influenced by M3 lags and also by previous values of GDP, the rest of the coefficients not being representative at the usual 5-10\% level of confidence.

\section{Conclusion}

Based on the analysis of knowledge and theories in the field we performed an analysis of the relationship that exists between the GDP and money supply. We made stationarity and cointegration tests, which showed that the analyzed series are non-stationary and we analyzed the co-integration between them, the conclusion reached is that the best model explicating the link between the two variables vector model DVAR autoregressive in its difference. 
The two equations are then:

$\mathrm{d} \_\mathrm{M} 3=0.65 * \mathrm{~d} \_\mathrm{M} 33_{-1}+0.41 * \mathrm{~d} \_\mathrm{M} 33_{-4}+\varepsilon_{\mathrm{t}}$ d_GDP $=3139.31+0.46 * \mathrm{~d}_{-} \mathrm{M} 3_{-1}+0.25 * \mathrm{~d} \_\mathrm{M} 3_{-3}-0.34 * \mathrm{~d} \_\mathrm{M} 3_{-5}-0.41 * \mathrm{~d}_{-}$GDP $-4-0.54 * \mathrm{~d}_{-} \mathrm{GDP}_{-6}$

Further research will be conducted and tests will be made on this type of model. Changes in GDP is explained much more consistent with a model type DVAR than the M3, also analyzing M3 series we note that the variation does not depend on gross domestic product but on its previous levels, thus an autoregressive(ARMA or ARCH ) model can be deployed in future. Further we propose the development and testing DVAR model and ARIMA model for the money series.

\section{References}

1. Adkins, L.C., 2009. Using Gretl for Principles of Econometrics, $3^{\text {rd }}$ Edition, www.learneconometrics.com

2. Bednarik, R., 2010. Money Supply and real GDP: The case of the Czech Republic, http://papers.ssrn.com/sol3/papers.cfm?abstract_id=1539390

3. Blundell-Wignall, A, Rondoni, M., Ziegelschmidt, H., 1984. The demand for Money and Velocity in Major OECD Countries, http://ideas.repec.org/s/oec/ecoaaa3.html

4. Brand, C., Cassola N., 2000. A Money Demand System for Euro Area M3, http://econpapers.repec.org/paper/ecbecbwps/20000039.htm

5. Carter Hill, R., Griffiths, W., Lim, G., 2008. Principles of Econometrics, $3^{\text {rd }}$ Edition, Editura John Wiley\& Sons

6. Codirlasu, A., 2008. Econometrie aplicata utilizand Eviews 5.1, www.dofin.ase.ro/acodirlasu

7. Cuevas, M.A., 2002. Money demand in Venezuela: Multiple Cycle Extraction in a Cointegration Framework, http://papers.ssrn.com/sol3/papers.cfm?abstract_id=313421

8. Hayo, Bernd, 2000. The Demand for Money in Austria, http://papers.ssrn.com/sol3/papers.cfm?abstract_id=262335

9. Mester, I., 2007. Econometrics, Editor University of Oradea.

10. Ozturk, IIhan, Acaravci A., 2008. The Demand for Money in Transition Economies, Romanian Journal of Economic Forecasting, no. 2, http://www.ipe.ro/rjef.htm

11. Pop Silaghi, M.I., Exports-Economic growth causality: Evidence from CEE Countries, Romanian Journal of Economic Forecasting, 2/2009, http://www.ipe.ro/rjef.htm

12. Zapodeanu D., 2002. Monetary Politics, Dacia Publishing House, Cluj-Napoca.

13. www.bnro.ro/PublicationDocuments.aspx ?icid $=1182$

14. www.gretl.sourceforge.net

15. http://www.census.gov/srd/www/x12a/ 